Supplement of Earth Syst. Dynam. Discuss., 6, 1445-1497, 2015

http://www.earth-syst-dynam-discuss.net/6/1445/2015/

doi:10.5194/esdd-6-1445-2015-supplement

(C) Author(s) 2015. CC Attribution 3.0 License.

(c) (i)

Supplement of

\title{
Climate change increases riverine carbon outgassing while export to the ocean remains uncertain
}

\section{F. Langerwisch et al.}

Correspondence to: F. Langerwisch (langerwisch@ pik-potsdam.de)

The copyright of individual parts of the supplement might differ from the CC-BY 3.0 licence. 


\section{Respiration of litter and soil carbon}

2 The respiration of the un-respired litter carbon and the soil carbon has been calculated analogous

3 to the LPJmL functions with Eqs. (S1) to (S12)

$$
\begin{aligned}
& \text { Litc }_{\text {unresp }} \text { loss }=\text { Litc }_{\text {unresp }} \times\left(1-e^{-\left(\text {respi }_{\text {litc }} \times \text { Tresponse }_{t}\right)}\right) \\
& \text { Litc }_{\text {loss }}=\text { Litc }_{t} \times\left(1-e^{-\left(\text {respi }_{\text {litc }} \times \text { Tresponse }_{t}\right)}\right) \\
& \text { lrLitc }_{\text {unresp }_{t}}=\text { Litc }_{\text {unresp }_{t}}-\text { Litc }_{\text {unresp }} \text { loss }_{\text {S }} \\
& \operatorname{lrLitc}_{t}=\text { Litc }_{t}-\text { Litc }_{\text {loss }} \\
& \text { Litc }_{t}=\text { lrLitc }_{t}+\text { lr Litc }_{\text {unresp }_{t}} \\
& \text { lrSoilc }_{\text {fast }_{t}}=\text { Soilc }_{\text {fast }_{t}}+\text { respipart }_{\text {soilcfast }}\left(\text { Litc }_{\text {unresp }_{\text {loss }}}+\text { Litc }_{\text {unresp }_{\text {loss }}}\right)
\end{aligned}
$$

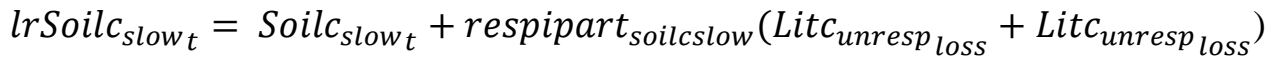

$$
\begin{aligned}
& \text { Soilc }_{\text {fast }} \text { loss }_{\text {lrSoilc }} \text { fast }_{t} \times\left(1-e^{-\left(\text {respi }_{\text {soilfast }} \times \text { Tresponse }_{t}\right)}\right) \\
& \text { Soilc }_{\text {slow }_{\text {loss }}}=\text { lrSoilc }_{\text {slow }_{t}} \times\left(1-e^{-\left(\text {respi }_{\text {soilslow }} \times \text { Tresponse }_{t}\right)}\right) \\
& \text { srSoilc }_{\text {fast }_{t}}=\text { lrSoilc }_{\text {fast }_{t}}-\text { srSoilc }_{\text {fast }_{\text {loss }}} \\
& \text { srSoilc }_{\text {slow }_{t}}=\text { lrSoilc }_{\text {slow }_{t}}-\text { srSoilc }_{\text {slow }} \text { loss } \\
& \text { Soilc }_{t}=\text { srSoilc }_{\text {fast }_{t}}+\text { srSoilc }_{\text {slow }_{t}}
\end{aligned}
$$

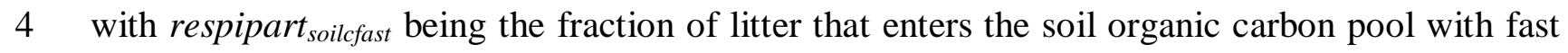
5 respiration and respipart soilslow $_{\text {being the fraction of litter that enters the soil organic carbon pool }}$ 6 with slow respiration. 


\section{Mobilization}

9 The mobilization takes place heterogeneously in the cell. It occurs first closest to the river. The

10 cells are therefore divided into fractions, which size depends on the vicinity to the river, with

11 section 6 close to the river.

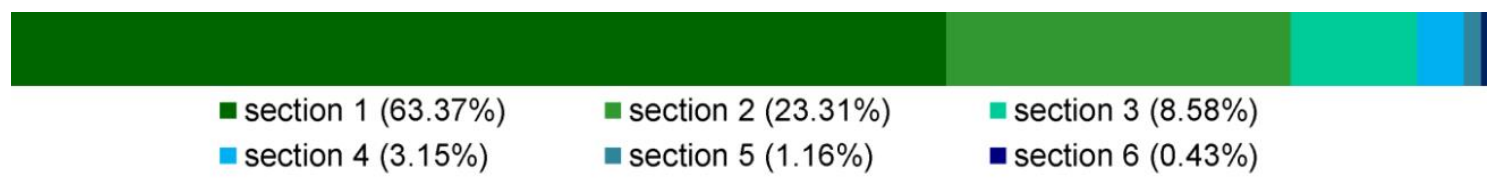

Figure S1: Depiction of the fraction of each cell section.

\section{$15 \quad 3 \quad$ Sensitivity analysis}

\subsection{Initial parameter setting and quality}

17 The parameterization of the model builds upon an analysis of the scientific literature. The parameters used within the model originate from a number of sources and are of differing quality. Table S1 lists all parameters and their sources. In addition to the parameter value, it also provides the value ranges and a first quality assessment of the parameter values based on the methods used in the relevant studies. The quality was weighted medium to low if the measurements took place in a slightly other system, for instance in the Igapó instead of Várzea, or are only based on one single observation. The quality and the relevance of single parameters for the simulation outputs are further tested in the sensitivity analysis.

Table S1: Initial parameter setting. List of parameters and parameter quality (high, medium, low).

\begin{tabular}{|c|c|c|c|c|c|}
\hline parameter name & \multicolumn{2}{|c|}{ initial value } & unit & source & quality \\
\hline \multicolumn{6}{|l|}{ mobilization } \\
\hline carboncorr & 0.65 & \pm 0.15 & month $^{-1}$ & (Worbes, 1997) & high \\
\hline mobil $_{\text {litc }}$ & 0.4 & \pm 0.1 & month $^{-1}$ & (Irmler, 1982) & medium \\
\hline mobil $_{\text {soilc }}$ & 0.008 & \pm 0.002 & month $^{-1}$ & (Irmler, 1982) & low \\
\hline mobil $_{p}$ & 0.5 & \pm 0.25 & - & $\begin{array}{l}\text { (McClain and Elsenbeer, 2001; } \\
\text { Johnson et al., 2006) }\end{array}$ & medium \\
\hline \multicolumn{6}{|l|}{ decomposition } \\
\hline decomp & 0.3 & \pm 0.1 & month $^{-1}$ & (Furch and Junk, 1997) & high \\
\hline decompcorr & 0.1 & \pm 0.01 & month $^{-1}$ & (Furch and Junk, 1997) & high \\
\hline \multicolumn{6}{|l|}{ respiration } \\
\hline respi & 0.045 & \pm 0.01 & day $^{-1}$ & (Cole et al., 2000) & high \\
\hline \multicolumn{6}{|l|}{ outgassing } \\
\hline co2satur & 7.25 to & 17.0 & - & (Richey et al., 2002) & high \\
\hline
\end{tabular}




\subsection{Simulations for sensitivity analysis}

The model RivCM has been run on a $0.5^{\circ} \times 0.5^{\circ}$ spatial resolution for the period 1901-2003. The transient runs have been preceded by a 90 -years-spinup during which the climate, $\mathrm{CO}_{2}$ levels and carbon input (litter and soil) of 1901-1930 have been repeated to obtain equilibrium for the riverine carbon pools. As input to the terrestrial litter and soil carbon pools, LPJmL results produced under the CRU TS2.1 climate (Österle et al., 2003; Mitchell and Jones, 2005) has been used. The transient LPJmL runs have been preceded by a 1,000-years-spinup during which the pre-industrial $\mathrm{CO}_{2}$ level of $280 \mathrm{ppm}$ and the climate of the years 1901-1930 have been repeated to obtain equilibrium for vegetation, carbon and, water pools. For this analysis, simulations have been conducted with an initial parameter setting (see Table S1) and a modified parameter setting (Table S2).

Table S2: List of parameters modified for the sensitivity analysis. All parameters have been multiplied with the following factors: $0.1 ; 0.5 ; 0.9 ; 1.1 ; 1.5 ; 1.9$.

\begin{tabular}{|c|c|c|}
\hline parameter name & $\begin{array}{l}\text { original } \\
\text { value }\end{array}$ & modified value \\
\hline \multicolumn{3}{|l|}{ mobilization } \\
\hline mobil $_{\text {litc }}$ & 0.4 & $0.04 ; 0.2 ; 0.36 ; 0.44 ; 0.6 ; 0.76$ \\
\hline mobil $_{\text {soilc }}$ & 0.008 & $0.0008 ; 0.004 ; 0.0072 ; 0.0088 ; 0.012 ; 0.0152$ \\
\hline mobil $_{p}$ & 0.5 & $0.05 ; 0.25 ; 0.45 ; 0.55 ; 0.75 ; 0.95$ \\
\hline \multicolumn{3}{|l|}{ decomposition } \\
\hline decomp & 0.3 & $0.03 ; 0.15 ; 0.27 ; 0.33 ; 0.45 ; 0.57$ \\
\hline \multicolumn{3}{|l|}{ respiration } \\
\hline respi & 0.045 & $0.0045 ; 0.0225 ; 0.0405 ; 0.0495 ; 0.0675 ; 0.0855$ \\
\hline
\end{tabular}

The sensitivity analysis aims to estimate the effect of changes in the explaining variables on the response variables. The results of these simulations have been analysed with a redundancy analysis (RDA). This analysis is, comparable to PCA, an ordination technique which identifies the most important separator of a given dataset (including all response variables) and also the most important initiator (explaining variables) of dataset's variability. The sensitivity analysis led to a partly adapted parameter setting (standard parameters). For evaluation, simulations under the standard parameter setting (see Table 3 row 'original value') have been conducted. The results of these simulations have been compared to several observed values (Table 4).

\subsection{Results of sensitivity analysis}

The aim of a sensitivity analysis is to estimate which output variable (response variable) is most sensitive to changing parameters (explaining variables), and which parameter changes cause the larges shifts in the output values. 
To analyse the results of the simulation of the sensitivity analysis a redundancy analysis (RDA) has been performed. The results of the redundancy analysis (for parameters see Table S2) are summarized in and Table S3. This analysis shows the effect of the explaining variables, i.e. parameters, mobil litc, mobil soilc, mobil $l_{p}$, decomp and respi on the response variables riverine particulate organic carbon (POC), riverine dissolved organic carbon (DOC), riverine inorganic carbon (IC) and outgassed carbon. The parameter changes did not cause changes in IC, since it is only temperature and atmospheric $\mathrm{CO}_{2}$ dependent. Therefore, IC has not been included in this 63 analysis.

64 The RDA shows that $79.2 \%$ of the variance within the dataset can be described by the explaining 65 variables (therefore, $20.8 \%$ cannot be explained by explaining variables).

66 The first, second, and third axis explain 54\%, 18.9\%, and $6.3 \%$ of the variance within the 67 dataset, respectively. The variance of the response variables TOC concentration, DOC 68 concentration, and POC concentration are mainly influenced by the first axis (RDA1) with loadings ( rop) of $-0.23,-0.21$, and -0.18 , respectively (depicted in red in Figure S2, listed in 70 Table S3). This axis is primarily controlled by respi (0.79) and mobil litc $(-0.59)$ (blue arrows in Figure S2). The variance of the response variable outgassed $\mathrm{CO}_{2}$ is mainly influenced by RDA2

72 with a loading of -0.075 . This axis is also primarily controlled by respi $(-0.60)$ and mobil $l_{\text {litc }}$ 73 (-0.78), but in a swapped order and, in contradiction to RDA1, not in opposite directions. The 74 third axis (RDA3) mainly influences the response variables POC concentration and DOC 75 concentration, with loadings of 0.013 and -0.008 , respectively. This axis is primarily controlled 76 by mobil $_{p}(0.81)$ and decomp $(-0.59)$.

77 Therefore, the parameters that explain most of the variance within the dataset are respi and 78 mobil $_{\text {litc. }}$ The parameters mobil $_{p}$ and decomp have only little effect on the variance of the whole 79 dataset. The most and nearly equally influenced output variables are TOC concentration and 80 DOC concentration. POC concentration and outgassed $\mathrm{CO}_{2}$ are only marginally affected. 


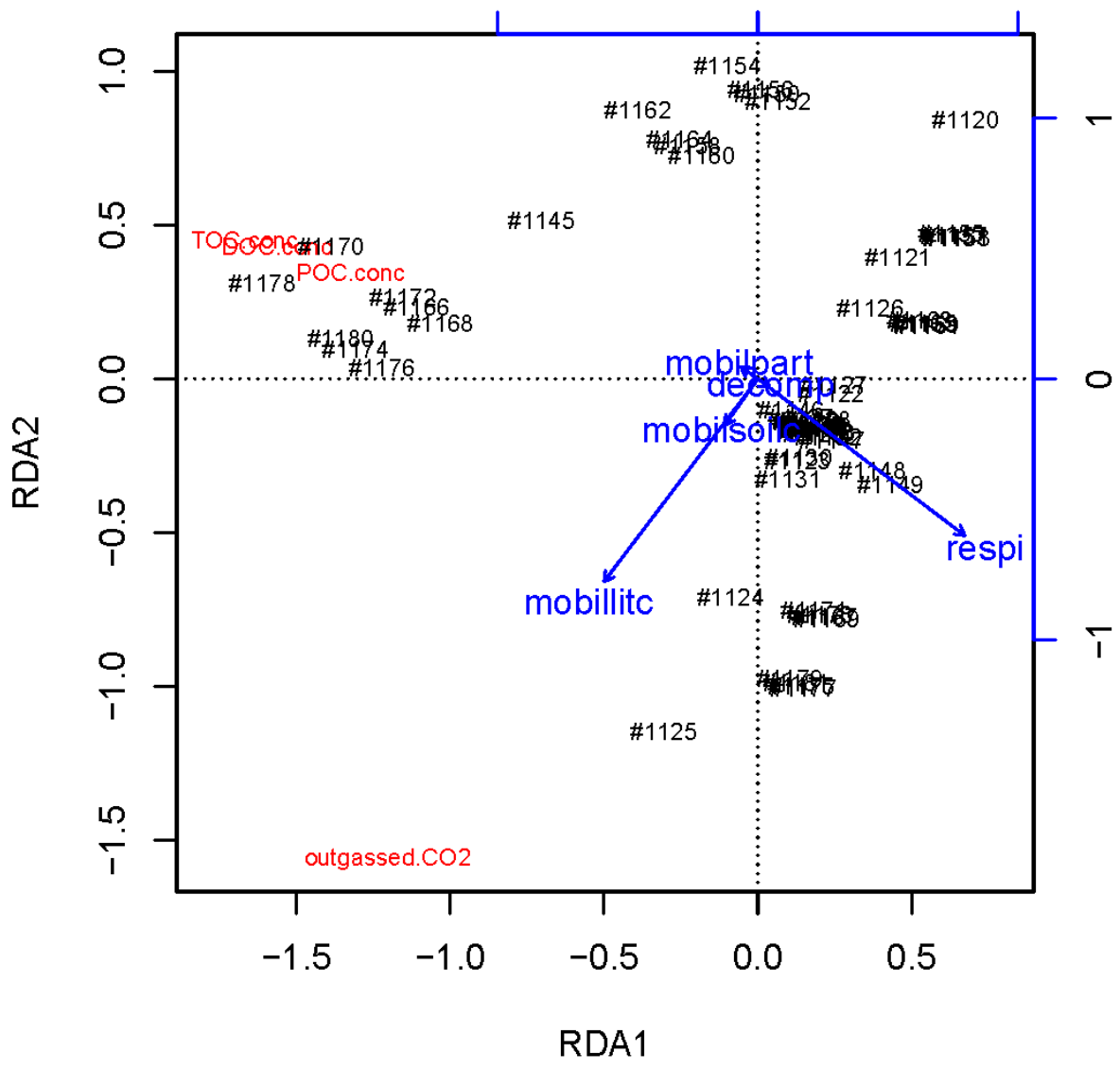

Figure S2: Results of the redundancy analysis. Redundancy analysis with all simulations associated with the sensitivity analysis (black numbers). The four output variables (red) have been calculated with five parameters (blue).

.

Table S3: Results of the redundancy analysis. Results for the first three RDA axes. Original value per axis (axis) and values proportional to the explained variability of the whole dataset (prop) with a general scaling constant of species scores of $\mathrm{Cs}=3.9523$.

\begin{tabular}{|c|c|c|c|c|c|c|}
\hline & \multicolumn{2}{|l|}{ RDAl } & \multicolumn{2}{|l|}{$R D A 2$} & \multicolumn{2}{|l|}{$R D A 3$} \\
\hline \multicolumn{7}{|c|}{ Proportion explained } \\
\hline & \multicolumn{2}{|l|}{0.540} & \multicolumn{2}{|l|}{0.189} & \multicolumn{2}{|l|}{0.063} \\
\hline \multicolumn{7}{|c|}{ Species scores (response variables) } \\
\hline & axis & prop & axis & prop & axis & prop \\
\hline TOC concentration & -1.668 & -0.228 & 0.4523 & 0.0216 & -0.1601 & -0.0026 \\
\hline POC concentration & -1.325 & -0.181 & 0.3446 & 0.0165 & 0.8283 & 0.0132 \\
\hline DOC concentration & -1.564 & -0.214 & 0.4296 & 0.0205 & -0.5249 & -0.0084 \\
\hline outgassed $\mathrm{CO}_{2}$ & -1.204 & -0.164 & -1.5634 & -0.0748 & -0.0080 & -0.0001 \\
\hline \multicolumn{7}{|c|}{ Variable scores (explaining variables) } \\
\hline & axis & prop & axis & prop & axis & prop \\
\hline mobil $_{\text {litc }}$ & -0.5900 & -0.3185 & -0.77757 & -0.14696 & -0.00312 & -0.00020 \\
\hline mobil $_{\text {soilc }}$ & -0.1262 & -0.0681 & \begin{tabular}{|c|c|}
-0.17715 \\
\end{tabular} & \begin{tabular}{|c|}
-03348 \\
\end{tabular} & -0.00110 & \begin{tabular}{|c|}
-0.00007 \\
\end{tabular} \\
\hline mobil $_{p}$ & -0.0650 & -0.0351 & 0.04598 & 0.00869 & 0.80759 & 0.05104 \\
\hline decomp & 0.0452 & 0.0244 & -0.03163 & -0.00598 & -0.58934 & -0.03725 \\
\hline respi & 0.7941 & 0.4287 & -0.60111 & -0.11361 & 0.08909 & 0.00563 \\
\hline
\end{tabular}




\section{Calibration and validation}

92 As a result of the sensitivity analysis, we calibrated values of the most important explaining 93 variables (parameters) mobil $_{\text {litc }}$, mobil soilc $_{\text {and }}$ respi (Tables 3, 4 and S4). After calibration the

94 Willmott's Index of Agreement, with 1 indicating complete agreement between observation and 95 simulation results (Willmott, 1982), is 0.615 , compared to 0.427 with the initial parameter values

96 (Table 4). The calibrated rate of respiration (respi) lies within the observed range, while the two 97 other calibrated parameters $\left(\right.$ mobil $_{\text {litc }}$, mobil $\left._{\text {soilc }}\right)$ are larger than observed values by a factor of 1.4 98 and 5, respectively (Table 3). However, the observations available were only conducted in a 99 Várzea ecosystem and mobil $_{\text {soilc }}$ and are only estimated.

100 Spatial pattern and distribution of the carbon pools as calculated with the standard parameter 101 setting are shown in Figure 4. The two organic carbon pools POC and DOC show the same 102 spatial pattern with high amounts concentrated along the river, and only differ in the actual 103 values with POC displaying half the amount of DOC (max. $0.2 \times 10^{8} \mathrm{~g} \mathrm{~km}^{-2}$ vs. max. $1040.4 \times 10^{8} \mathrm{~g} \mathrm{~km}^{-2}$, Fig. S3). In contrast, the two inorganic carbon pools differ in their spatial 105 pattern. The amount of inorganic carbon per cell (IC) increased up to $0.25 \times 10^{8} \mathrm{~g} \mathrm{~km}^{-2}$ with 106 increasing river discharge. The outgassed carbon is more homogeneously distributed in the 107 catchment. Here, also the river network in combination with the floodplain can be identified. 108 Therefore, the pattern is less pronounced than in the other carbon pools. 
A

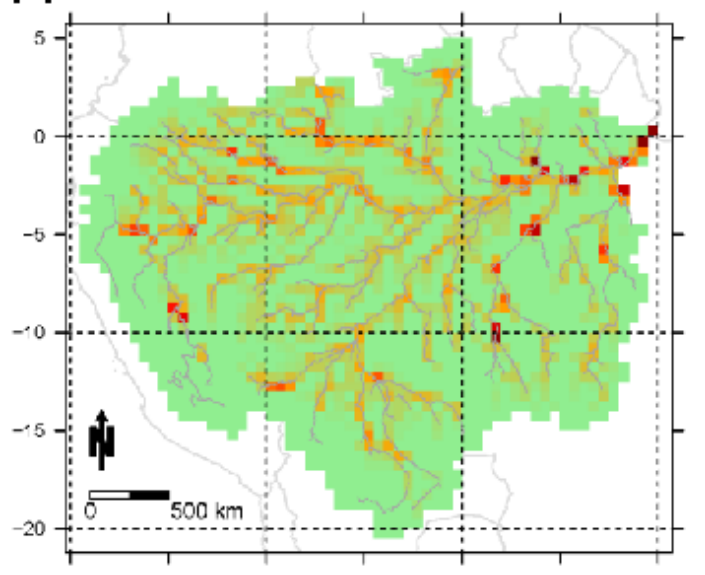

C

110

111

112

113

114

115 simulations forced by CRU TS2.1.
B
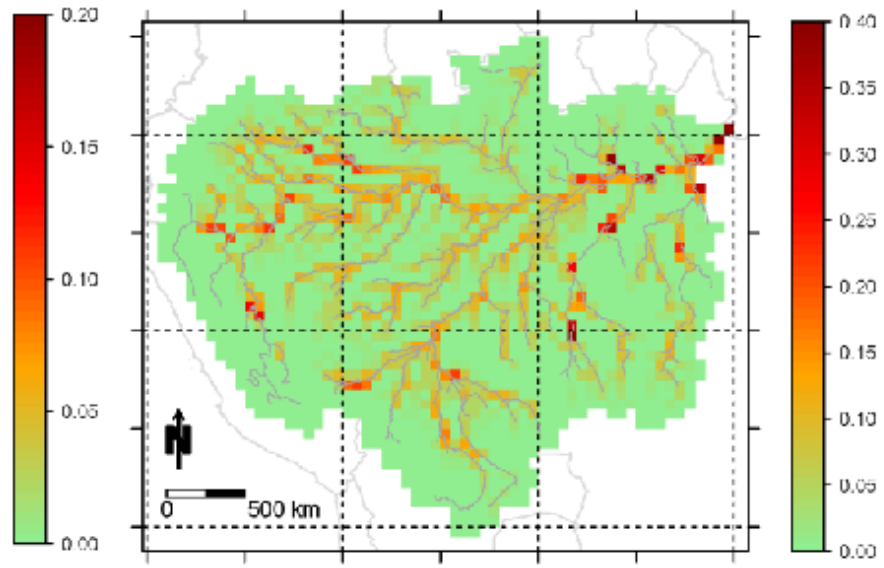

D
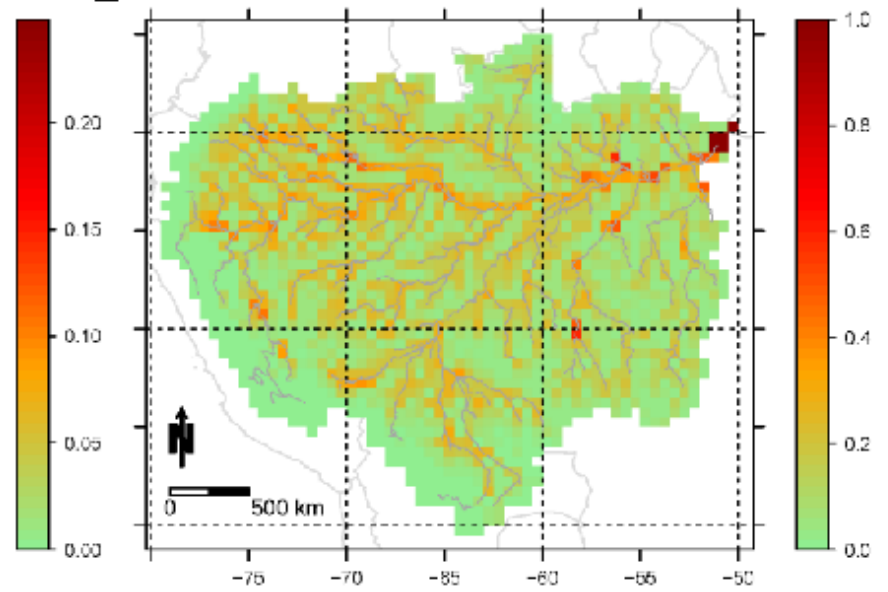

Figure S3: Spatial distribution of the four carbon species used in the further analysis. Riverine particulate organic (POC), dissolved organic (DOC) and inorganic carbon (IC), and outgassed carbon [108 g km-2] in 2003 obtained from
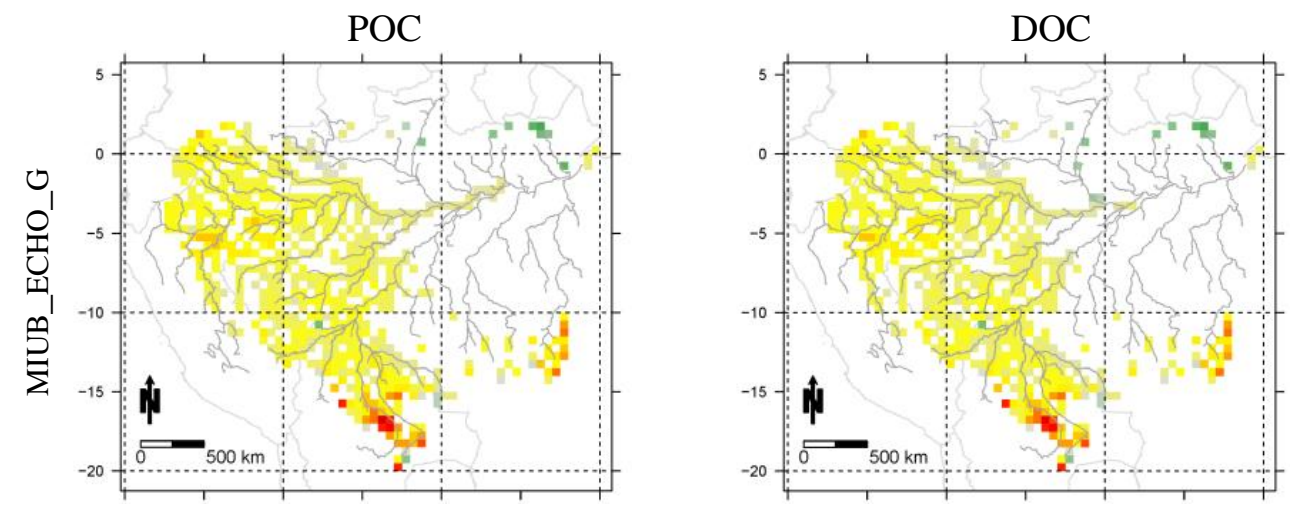

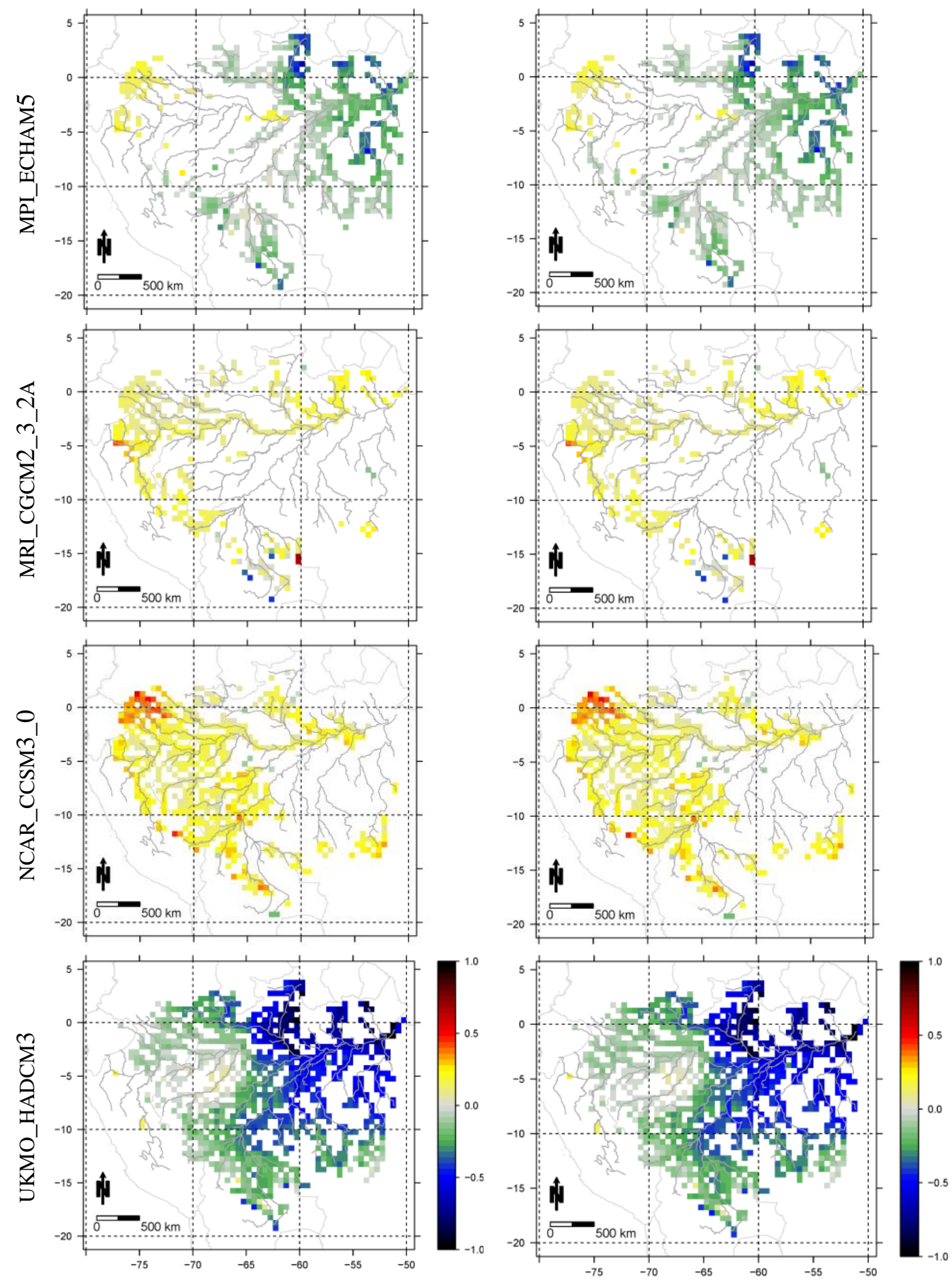

Figure S4: Changes in particulate organic carbon (POC) and dissolved organic carbon (DOC) caused by climate change. Quotient $(\log 10)$ of mean future and mean reference carbon amount for each climate model/scenario under emission scenario A1B. Positive values indicate an increase and negative values indicate decrease. 


\section{References}

124 Belger, L., Forsberg, B. R. and Melack, J. M.: Carbon dioxide and methane emissions from 125 interfluvial wetlands in the upper Negro River basin, Brazil, Biogeochemistry, 105, 171-183, 126 doi:10.1007/s10533-010-9536-0, 2011.

127 Cole, J. J., Pace, M. L., Carpenter, S. R. and Kitchell, J. F.: Persistence of net heterotrophy in lakes during nutrient addition and food web manipulations, Limnol. Oceanogr., 45(8), 1718$1730,2000$.

130 Devol, A. H., Quay, P. D., Richey, J. E. and Martinelli, L. A.: The role of gas-rxchange in the inorganic carbon, oxygen, and Rn-222 budgets of the Amazon river, Limnology and Oceanography, 32(1), 235-248, 1987.

Furch, K. and Junk, W. J.: The chemical composition, food value, and decomposition of herbaceous plants, leaves, and leaf litter of floodplain forests, in The Central Amazon Floodplain, edited by W. J. Junk, pp. 187-205, Springer, Berlin, Germany., 1997.

Irmler, U.: Litterfall and nitrogen turnover in an Amazonian blackwater inundation forest, Plant and Soil, 67(1-3), 355-358, 1982.

Johnson, M. S., Lehmann, J., Selva, E. C., Abdo, M., Riha, S. and Couto, E. G.: Organic carbon fluxes within and streamwater exports from headwater catchments in the southern Amazon, Hydrological Processes, 20(12), 2599-2614, 2006.

Junk, W. J. and Wantzen, K. M.: The flood pulse concept: New aspects, approaches and applications - An update, in Proceedings of the Second International Symposium on the Management of large Rivers for Fisheries, edited by R. L. Welcomme and T. Petr, pp. 117-140., 2004.

Lewin-Koh, N. J. and Bivand, R.: maptools: Tools for reading and handling spatial objects. R package version 0.8-7., 2011.

McClain, M. E. and Elsenbeer, H.: Terrestrial inputs to Amazon streams and internal 148 biogeochemical processing, in The Biogeochemistry of the Amazon Basin, edited by M. E. McClain, R. L. Victoria, and J. E. Richey, pp. 185-208, Oxford University Press, New York., 2001.

Melack, J. M. and Forsberg, B.: Biogeochemistry of Amazon floodplain lakes and associated wetlands, in The Biogeochemistry of the Amazon Basin and its Role in a Changing World, pp. 235-276, Oxford University Press, Eds. McClain, M. E.; Victoria, R. L.; Richey, J. E., 2001. watershed, Biogeochemistry, 105, 133-147, doi:10.1007/s10533-011-9581-3, 2011. 
159 Poulter, B., Aragão, L., Heyder, U., Gumpenberger, M., Heinke, J., Langerwisch, F., Rammig, 160 A., Thonicke, K. and Cramer, W.: Net biome production of the Amazon Basin in the 21st 161 century, Global Change Biology, 16(7), 2062-2075, doi:10.1111/j.1365-2486.2009.02064.x, 1622009.

163 Rammig, A., Jupp, T., Thonicke, K., Tietjen, B., Heinke, J., Ostberg, S., Lucht, W., Cramer, W. 164 and Cox, P.: Estimating the risk of Amazonian forest dieback, New Phytologist, 187(3), 694165 706, doi:10.1111/j.1469-8137.2010.03318.x, 2010.

166 R Development Core Team and contributors worldwide, N. J.: stats: The R Stats Package version 167 2.13.0., 2011.

168 Richey, J. E., Melack, J. M., Aufdenkampe, A. K., Ballester, V. M. and Hess, L. L.: Outgassing 169 from Amazonian rivers and wetlands as a large tropical source of atmospheric $\mathrm{CO}_{2}$, Nature, 170 416(6881), 617-620, doi:10.1038/416617a, 2002.

171 Silva, T. S. F., Costa, M. P. F. and Melack, J. M.: Annual net primary production of macrophytes 172 in the Eastern Amazon floodplain, Wetlands, 29(2), 747-758, 2009.

173 Sippel, S. J., Hamilton, S. K. and Melack, J. M.: Inundation area and morphometry of lakes on 174 the Amazon River floodplain, Brazil, Archiv Fuer Hydrobiologie, 123(4), 385-400, 1992.

175 Willmott, C. J.: Some comments on the evaluation of model performance, Bulletin American 176 Meteorological Society, 63(11), 1309-1313, 1982.

177 Worbes, M.: The forest ecosystem of the floodplains, in The Central Amazon Floodplain, edited 178 by W. J. Junk, pp. 223-265, Springer, Berlin, Germany., 1997. 